\title{
Geochemistry, petrology and evolutionary computations in the service of archaeology: restoration of the historical smelting process at the Katowice-Szopienice site
}

\author{
Rafał Warchulski ${ }^{1}$ - Przemysław Juszczuk ${ }^{2}$ - Aleksandra Gawȩda ${ }^{3}$
}

Received: 26 May 2016 / Accepted: 4 November 2016/Published online: 16 November 2016

(C) The Author(s) 2016. This article is published with open access at Springerlink.com

\begin{abstract}
Activity at the smelting plant at KatowiceSzopienice dates back to the nineteenth century. Currently, the Museum of Zinc has been funded at the site. Unfortunately, as a result of unrest during both World Wars, all technological descriptions were lost. Three historically described samples were provided by Museum of Zinc and additional slag and lining samples were collected directly from the furnace. "Enriched ore" is dominated by $\mathrm{ZnS}$ $(89.5 \%)$ as sphalerite and wurtzite accompanied by gangue minerals. "Roasted ore" is composed mainly of zincite (74\%) resulting from the oxidation of $\mathrm{ZnS}$. Study has proved that "roasted ore with coke" sample description is inappropriate. It is zinc depleted and enriched in $\mathrm{Si}(22.93$ wt.\%), $\mathrm{Al}$ (9.16 wt.\%), C (9.66 wt.\%) and its phase composition suggest that it contains recycled lining material and coke. Such characteristics place sample as additions used for smelting process. Advanced mathematical tool, the differential evolution algorithm, was used for restoration of smelting process at the site. Algorithm proved great usefulness by providing low dispersed results for calculated compositions of loss on smelting (mainly yield) with the
\end{abstract}

Rafał Warchulski

rwarchulski@us.edu.pl

1 Centre for Polar Studies KNOW (Leading National Research Centre), Faculty of Earth Sciences, University of Silesia, Sosnowiec, Poland

2 Faculty of Informatics and Communication, Chair of Knowledge Engineering, University of Economics, Katowice, Poland

3 Department of Earth Sciences, University of Silesia, Sosnowiec, Poland fitting error reduced down to $1.19 \mathrm{wt} . \%$. Loss on smelting composition was dominated by $\mathrm{Zn}$ (41.40 wt.\%), Si (9.67 wt.\%) and C (9.50 wt.\%). Proportion of roasted ore to addition in smelting process was estimated as 1:1.27 and loss on smelting share from batch was $62 \%$. Geochemistry and petrology have provided rich qualitative information about the samples and smelting process, but in combination with evolutionary computations, high-quality quantitative data were obtained.

Keywords Smelting process · Geochemistry · Petrology · Evolutionary computations

\section{Introduction}

Pyrometallurgical slags are currently extensively studied, the investigations mostly being focused on the slag's environmental impact (e.g. Kierczak et al. 2010; Piatak and Seal II 2010; Ettler and Johan 2014; Warchulski et al. 2015) or on their potential commercial usage (e.g. Sybilski et al. 2004). Slags, as analogues of silicate melts, also offer the possibility of describing the unique process of melt crystallization (Puziewicz et al. 2007; Warchulski et al. 2016).

In many cases, historical information about the smelting process is fully or partially lost and slags are the only remnants of the smelting plants. Thus, they are of interest as carriers of geochemical/mineralogical data that can be used for the restoration of ancient smelting processes at historical sites (Manasse and Mellini 2002a, b; Kierczak and Pietranik 2011; Warchulski 2015).

Slag heaps are a common feature of the Upper Silesia landscape, a result of the extensive exploitation of the Mississippi Valley-type zinc-lead ores in the Cracov-Silesia district, dating back to the eleventh century. The ores are 
composed mainly of sulphides (sphalerite, pyrite, marcasite, galena) coexisting with galmans, all hosted in dolomitic rocks (Heijlen et al. 2003). Up to the nineteenth century, the properties of zinc were not investigated and zinc-bearing minerals were treated as contamination of lead and silver ores. Technological developments in the nineteenth century created a growing need for zinc in the market and resulted in zinc exploitation and smelting.

The Katowice-Szopienice smelting plant (Fig. 1) was active for 174 years till 2008. For the sake of the sustainable exploitation of national deposits and the best quality of the products, import of ores from Germany, and in smaller quantities from Romania, was also implemented (Dobis 1938). All technological documentation of the historical processes used in this smelting plant was lost during World War II. That is, unfortunately, the common case for smelting sites in Poland (e.g. Warchulski et al. 2015). Existing descriptions are based on general historical publications concerning non-ferrous smelting in the Silesia-Cracow area (e.g. Greiner 2004).

According to historical descriptions, a three-stage process was applied in the Katowice-Szopienice smelter. The first stage was ore enrichment, by rinsing and flotation, up to $60 \mathrm{wt} . \% \mathrm{Zn}$. In the second stage, after enrichment, the ore was roasted in shaft kilns and during that process sulphuric acid was manufactured as by-product. The third stage was a proper smelting of the roasted ore with additions and coke as a reduction agent. The whole process was conducted in muffles with attached receivers. Zinc as a vapor migrated from the muffle to a receiver where it was collected as a metal (Dobis 1938).

At the Katowice-Szopienice smelting site, all slag heaps resulting from the smelting plant activity were used for commercial purposes, but the Museum of Zinc, formed at the site, has stored technological samples of enriched ore, roasted ore, and roasted ore with coke. A few slag samples were also collected from historical muffles stored in the Museum.

The main goal of this paper is to reproduce the historical smelting process at the Katowice-Szopienice smelting site on the basis of historical, mineralogical and geochemical data. A Secondary goal is to verify the historical descriptions of the technological samples and track the changes of ore chemistry and phase composition during each step of the technological process, supported by evolutionary computations. Investigations in this study are based on the rare situation where not only the slags are preserved but also material from every step of the smelting process as well.
Fig. 1 Localization of the Museum of Zinc in Katowice within Upper Silesia region (Polish part)

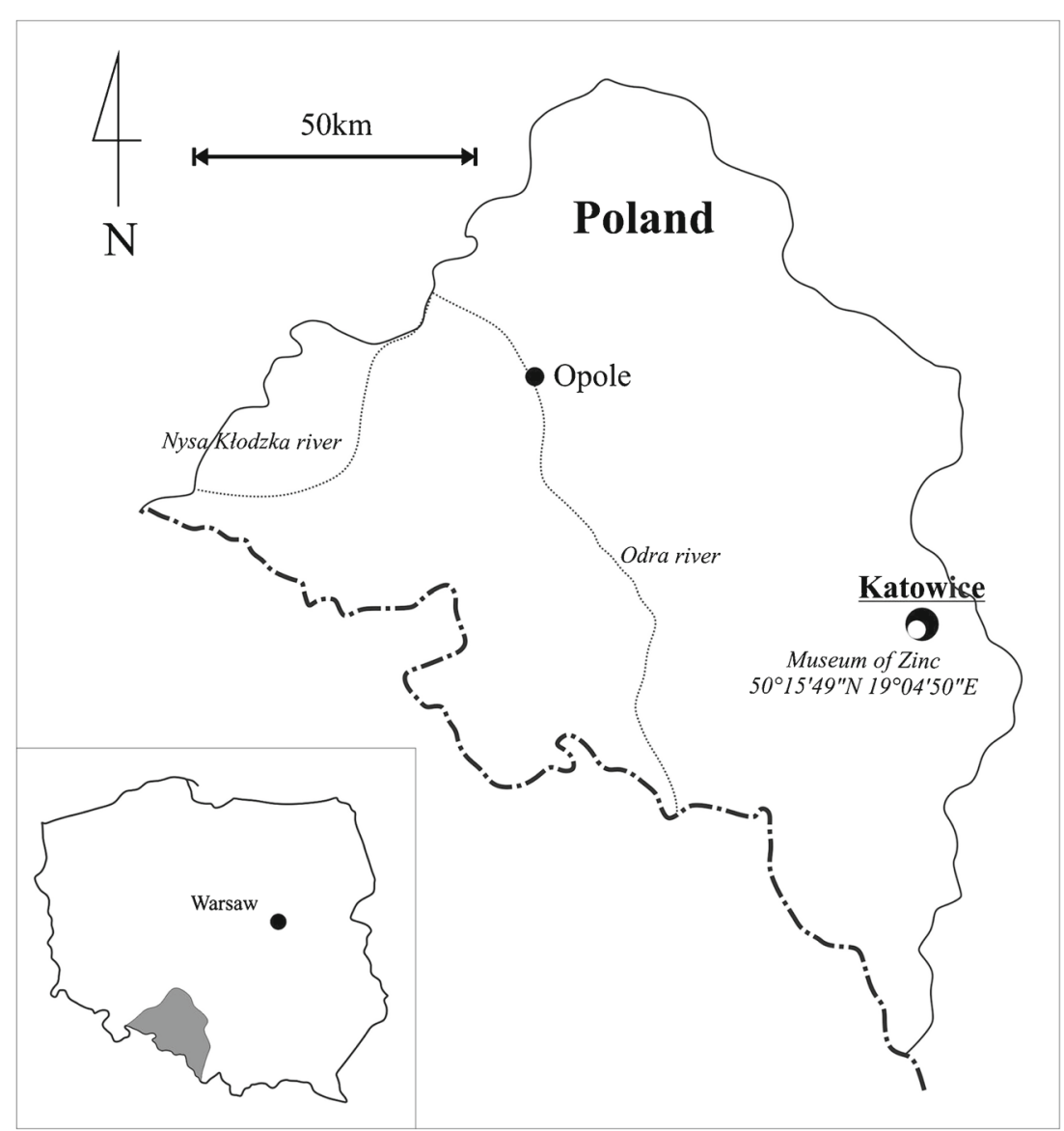




\section{Sampling and experimental methods}

Five samples were collected from Museum of Zinc in Katowice-Szopienice. Three of them, stored in sealed jar, are historically described as enriched ore, roasted ore and roasted ore with coke. Regular slag was sampled directly from the muffle, as a group of 12 nodules, whilst slag from the contact with the lining (fireclay brick) was taken from the Museum of Zinc collection. It should be taken into account that the descriptions of sealed samples were made by smelting plant workers at an unknown time, and should be treated as uncertain.

Thin sections of slag samples were examined on a ZX10 binocular microscope and an Olympus BX-51 polarizing microscope, and using an analytical scanning electron microscope (SEM; FET Philips XL30) equipped with an energy-dispersive spectrometer (EDS). The phase compositions and proportion of phases in samples were determined by X-ray diffraction using PANalytical X'PERT PRO - PW 3040/60 using Co K $\alpha 1$ radiation (Fe filter) with software $\mathrm{K} \alpha 2$ stripping (Rachinger 1948; Ladell et al. 1975), $45 \mathrm{kV}$ voltage and intensity of $30 \mathrm{~mA}$.

Electron probe micro-analyses (EPMA) and backscattered electron (BSE) imaging of phases were performed using electron probe micro-analyser CAMECA SX 100 (Inter-Institutional Laboratory of Microanalysis of Minerals and Synthetic Materials, the Warsaw University). Conditions during analyses: $15 \mathrm{keV}$ accelerating voltage, 10-20.1 nA beam current and beam diameter of up to $5 \mu \mathrm{m}$. Standards included: $\mathrm{Al}-\mathrm{KAlSi}_{3} \mathrm{O}_{8} ; \mathrm{Ca}-\mathrm{CaSiO}_{3} ; \mathrm{Fe}-\mathrm{Fe}_{2} \mathrm{O}_{3}$; $\mathrm{K}-\mathrm{KAlSi}_{3} \mathrm{O}_{8} ; \quad \mathrm{Mg}-\mathrm{MgCaSi}_{2} \mathrm{O}_{6} ; \quad \mathrm{Mn}-\mathrm{MnCO}_{3} ; \mathrm{Na}-$ $\mathrm{NaAlSi}_{3} \mathrm{O}_{8} ; \mathrm{Pb}-\mathrm{PbS}, \mathrm{PbCrO}_{4} ; \mathrm{S}-\mathrm{BaSO}_{4}, \mathrm{CuFeS}_{2}, \mathrm{ZnS}$; $\mathrm{Si}-\mathrm{CaSiO}_{3} ; \mathrm{Ti}-\mathrm{TiO}_{2} ; \mathrm{Zn}-\mathrm{ZnS}$.

The chemical compositions of samples were analyzed by $\mathrm{X}$-ray fluorescence (XRF) and inductively coupled plasma mass spectrometry (ICP-MS) at ACME Analytical Laboratories, Vancouver, Canada. The preparation consists of Lithium borate fusion and dilute digestions or hot four-acid digestion for ICP-ES, $\mathrm{LiBO}_{2}$ fusion for XRF and lithium borate decomposition, or aqua regia digestion for ICP-MS. LOI was determined at $1000{ }^{\circ} \mathrm{C}$. Each sample received from Museum of Zinc was averaged by reduction to the point of appropriate weight for the corresponding method.

\section{Evolutionary computations}

To achieve the goal of this study, which is a complete restoration of historical processes at the site, we have to answer the following questions: *What was the proportion of roasted ore to additions in the smelting process? ${ }^{* *}$ What percentage of the batch was transformed into slag and to loss on smelting? ${ }^{* * *}$ What was the composition of the loss on smelting? To accomplish these aims, we have to (1) experimentally verify the compatibility of available compositions with their expected weights, (2) approximate the weight proportions of compounds on the basis of the known compositions of the compounds and (3) determine the composition of the missing members. We propose an approximate approach based on metaheuristic methods, often called evolutionary computation. Evolutionary computation is a technique in which the optimization process is based on simple rules taken directly from biology (Engelbrecht 2007; Goldberg 1989). The proposed approach is mainly based on the transformation of the selected problem into a continuous optimization problem. In other words, the real-world problem is transformed into a multidimensional numerical vector, and the goal is to find the proper values of all vector elements.

Such an approach was used for example in filter design (Storn 1996) and image analysis (Kasemir 2003). In this paper, we propose an algorithm based on the evolutionary algorithms - the differential evolution. This method was originally proposed by Storn and Price (1997). The whole process is based on the assumption that the relationships between all chemical compounds (here: different samples) may be presented as a complex system of equations.

We have designed a set of equations. First of all, an overall weight equation was given as follows:

$w(A)+w(B)-w(C)=w(D)$,

where $w(A)$ is the total weight of the roasted ore, $w(B)$ is the total weight of the additions and the same applies for $w(C)$ which is the loss on smelting material and $w(D)$ which is the total weight of the slag. In the above equation, the weight of $B, C$ and $D$ are unknown and must be calculated on the basis of an assumed $A$ weight. Moreover, the same assumption must hold for every element:

$w\left(a_{i}\right)+w\left(b_{i}\right)-w\left(c_{i}\right)=w\left(d_{i}\right)$,

where $w\left(a_{i}\right)$ is the weight of the $i$ th element (respectively: $\mathrm{Si}, \mathrm{Al}$ etc.) in the roasted ore. All the above dependencies may be presented as a 42-dimensional variable vector, where the first 14 elements will be considered as weights of elements in the additions, the next 14 elements are the weights of elements in the loss on smelting material and finally the last part of the vector will be identified as the weights of elements in the slag. In further considerations, we call such a vector an individual. On the basis of the mentioned assumptions, we proposed the new approach based on the evolutionary computations, where in the first stage of the algorithm a randomly generated set of individuals are scattered uniformly in the 42-dimensional search space. In the next steps of the algorithm, every generated individual is modified in such way that the calculation error calculated on the basis of the components of each individual is 
minimized. According to the basic concepts of metaheuristic algorithms, in every iteration, individuals closest to the global minimum are preferred over individuals for which the computation error was larger than others. This method is presented by the algorithm 1 :

1. Generate the initial set of individuals $P_{0}=$ $\left\{\vec{x}_{1,0}, \vec{x}_{2,0}, \ldots, \vec{x}_{n, 0}\right\}$;

2. Modify the selected individuals in such way that the number of newly generated set of solutions $V_{G}$ is equal to the cardinality of the initial set;

3. Evaluate all individuals in both sets $P_{0}$ and $V_{G}$;

4. For the next iteration of the algorithm, select only individuals with the minimal error value;

5. If stop condition is not met go to step 2 .

Modification of the initial set of individuals is realized in step 2. This process is conducted on the basis of two phases. First of all, a new set of solutions based on the initial set of solutions is generated:

$\forall i, j V_{i, j}=V_{r_{1}, j}+F \cdot\left(V_{r_{2}, j}-V_{r_{3}, j}\right)$

where $i$ is the number of individuals in the set, $j$ is the element of the vector and $r_{1}, r_{2}$ and $r_{3}$ are random numbers of individuals in the set. $F$ is a scalar value called the mutation factor. Value of the $F$ was arbitrarily set to 0.7 . This process if called the mutation. In the second phase (also called the crossover), a random crossover of vectors is introduced. This process is given as follows:

$\forall i, j U_{i, j}=V_{i, j}$ if RandomNumber $<0.5$;

or

$\forall i, j U_{i, j}=P_{i, j}$ if RandomNumber $>0.5 ;$

where $i$ is the number of individual in the set, $j$ is the element of the vector, $P$ is the set of initial individuals, $V$ is the set of individuals after the mutation process, $U$ is the set of individuals after the mutation and crossover process and the Random Number is a random value selected uniformly from the range $\langle 0: 1\rangle$.

After that stage, two sets of solutions (with equal cardinality) are given in the algorithm. The first set is the original initial set, thus the second one is the set generated on the basis of mutation and crossover. The most complex process is individual evaluation in which every potential solution must be evaluated. This process is realized on the basis of fitness function build on the basis of the knowledge of the domain expert. In this article, the following fitness function is presented:

Fitness $=f_{1}+f_{2}+f_{3}+f_{4}$, where $f_{1}$ is calculated as follows:

$f_{1}=\sum_{i=1}^{n}\left|\operatorname{proposed}\left(b_{i}\right)-w(B) \cdot \operatorname{percentage}\left(b_{i}\right)\right|$,

where proposed $\left(b_{i}\right)$ is the weight of the $i$ th element in the addition proposed by the algorithm, $w(B)$ is the total weight of the addition calculated as a $\sum_{i=1}^{n} \operatorname{proposed}\left(b_{i}\right)$ and finally percentage $\left(b_{i}\right)$ is the known percentage value of the $i$ th element. The same equation should be applied to the calculation of the function $f_{2}$ which is calculated on the basis of the loss on smelting material data and finally $f_{3}$, which is the slag. The last element of the fitness function is calculated as follows:

$f_{4}=\sum_{i=1}^{n}\left|w\left(d_{i}\right)-\left(w\left(a_{i}\right)+w\left(b_{i}\right)-w\left(c_{i}\right)\right)\right|$,

where $w\left(a_{i}\right)$ is the given weight of the $i$ th element in the roasted ore; $w\left(b_{i}\right)$ is the calculated weight of the $i$ th element in the additions; $w\left(c_{i}\right)$ is the calculated weight of the $i$ th element in the loss on smelting material and $w\left(d_{i}\right)$ is the calculated weight of the $i$ th element in the slag.

The above issue is called the function minimization process; lowering the fitness function over time leads to a global optimum of the multidimensional continuous function. Finally, for the next iteration of the algorithm, only individuals with the lowest fitness function value are selected. Those elements replace the original initial set of individuals and the whole process is repeated as long as the stop criteria are not met.

\section{Results and disscusion}

\section{Sample description}

The yellow-greenish enriched ore sample is composed of grains of different size and colour, up to $5 \mathrm{~mm}$ in diameter (Fig. 2a). According to XRD data (Table 1), the enriched ore is composed of $81.5 \%$ sphalerite $(\mathrm{ZnS}), 8 \%$ wurtzite $(\mathrm{ZnS})$, $4.5 \%$ marcasite $\left(\mathrm{FeS}_{2}\right), 3 \%$ pyrite $\left(\mathrm{FeS}_{2}\right), 2.5 \%$ anglesite $\left(\mathrm{PbSO}_{4}\right)$ and $0.5 \%$ dolomite $\left(\mathrm{CaMg}\left(\mathrm{CO}_{3}\right)_{2}\right)$.

The roasted ore is composed of a mixture of white, red and brown gravels up to $5 \mathrm{~mm}$ in size (Fig. 2b). The main phase components are zincite $(\mathrm{ZnO} ; 74 \%)$, dolomite $(14.5 \%)$, plattnerite $\left(\mathrm{PbO}_{2} ; 4 \%\right)$, franklinite $\left(\mathrm{ZnFe}_{2} \mathrm{O}_{4}\right.$; $3 \%)$, anglesite $(2.5 \%)$, quartz $\left(\mathrm{SiO}_{2} ; 1 \%\right)$ and sphalerite $(\mathrm{ZnS} ; 1 \%)$ (Table 1). As the result of calcination, some $\mathrm{ZnS}$ was transformed to $\mathrm{ZnO}$ whilst the remaining $\mathrm{Zn}$, together with $\mathrm{Fe}$ from pyrite/marcasite, participated in the crystallization of franklinite. Crystallization of plattnerite was possible due to the presence of $\mathrm{Pb}$ in the enriched ore, 
Fig. 2 Microscopic and SEM images of $\mathbf{a}$ enriched ore, $\mathbf{b}$ roasted ore, $\mathbf{c}$ roasted ore with coke, $\mathbf{d}-\mathbf{e}$ slag and $\mathbf{f}-\mathbf{h}$ slag with lining material. crs cristobalite, cpx clinopyroxene, $g l s$ glass, $s p l$ spinel, $t r d$ tridimite
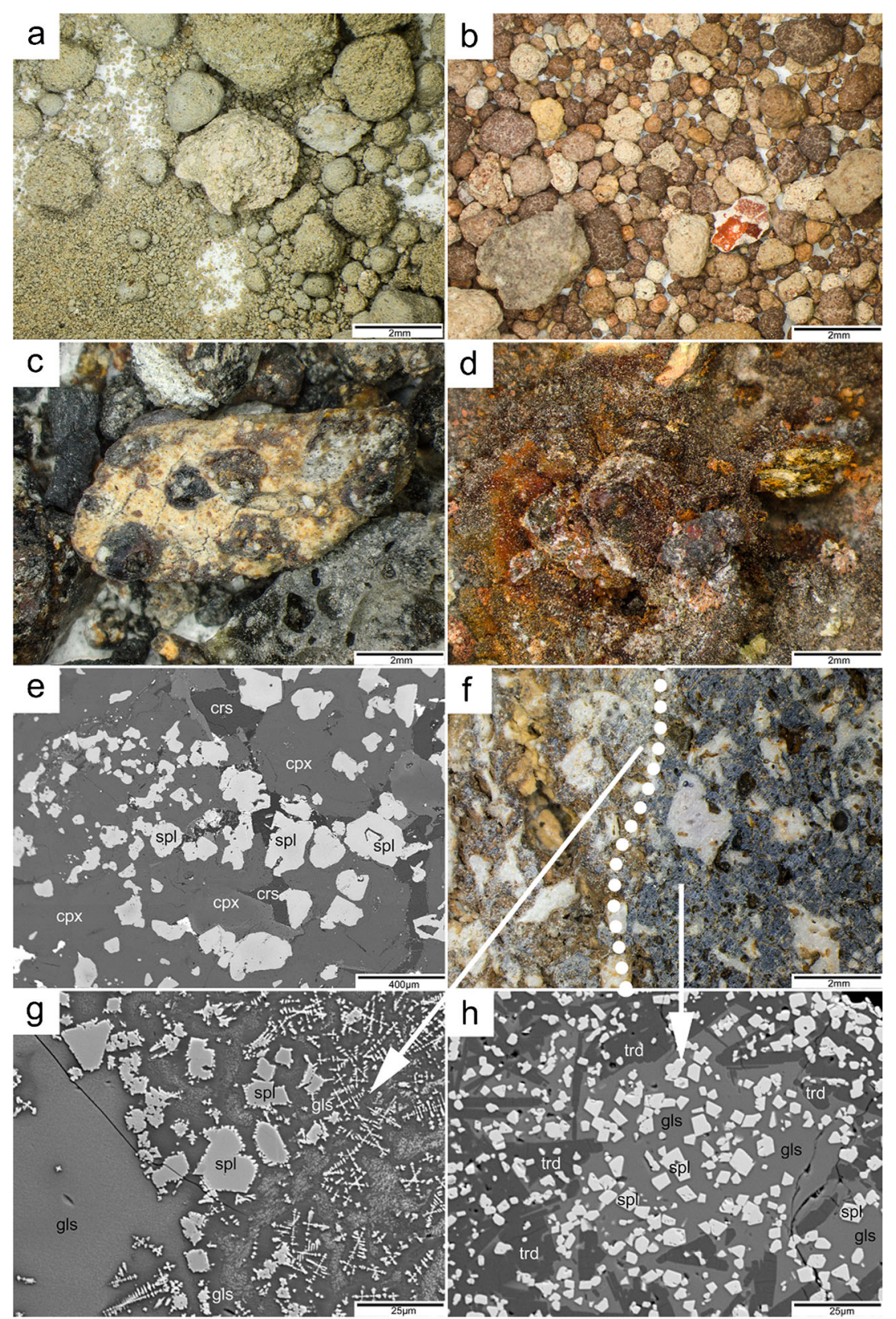

whilst during roasting process sulphur concentrated in residual sphalerite and anglesite. The surprisingly high content of dolomite suggests that the roasted ore sample is not a direct result of roasting of an enriched ore sample.

The roasted ore with coke is composed of grains up to $20 \mathrm{~mm}$ in diameter. Macroscopically, it is possible to distinguish three main types of grains in the sample: coke; slag-like; and lining-like (see: Fig. 2c). Inside the least common type, one can macroscopically determine some quartz grains. XRD analysis showed the presence of $42 \%$ quartz, $8 \%$ cristobalite $\left(\mathrm{SiO}_{2}\right), 23 \%$ mullite $\left(\mathrm{Al}_{6} \mathrm{Si}_{2} \mathrm{O}_{13}\right)$, $15.5 \%$ diopside $\left(\mathrm{CaMgSi}_{2} \mathrm{O}_{6}\right)$ and $1.5 \%$ calcite $\left(\mathrm{CaCO}_{3}\right.$; Table 1). Coke composes around $10 \%$ of the sample. Such a composition is surprising in the context of historical sample descriptions. The expected composition should be similar to that of the roasted ore enriched in coke. Ores do not have compositions which allow them to crystallize such amounts of $\mathrm{SiO}_{2}$ and $\mathrm{Al}_{2} \mathrm{O}_{3}$ bearing minerals; also, the temperature conditions during roasting were unlikely to be sufficient for cristobalite to crystallize. Analysed material does not contain any Zn-minerals, only diopside may concentrate some minor amounts of this element (Warchulski et al. 2015). On the other hand, the presence of coke suggests that this sample should be connected with $\mathrm{ZnO}$ reduction during the smelting. A possible explanation is that this sample represent additions to the ore before smelting.

Slag is composed of nodules up to $7 \mathrm{~cm}$ in size, with various morphologies and colours (Fig. 2d). Slags from 
Table 1 Samples phase composition based on XRD data

\begin{tabular}{|c|c|c|c|c|c|}
\hline & Enriched ore & Roasted ore & Roasted ore with coke & Slag & Slag with lining material \\
\hline Sphalerite & 81.50 & 1.00 & - & - & - \\
\hline Wurtzite & 8.00 & - & - & - & - \\
\hline Marcasite & 4.50 & - & - & - & - \\
\hline Pyrite & 3.00 & - & - & - & - \\
\hline Anglesite & 2.50 & 2.50 & - & - & - \\
\hline Dolomite & 0.50 & 14.50 & - & - & - \\
\hline Franklinite & - & 3.00 & - & - & - \\
\hline Augite & - & - & - & 62.00 & - \\
\hline Zincite & - & 74.00 & - & - & - \\
\hline Plattnerite & - & 4.00 & - & - & - \\
\hline Quartz & - & 1.00 & 42.00 & - & 4.50 \\
\hline Mullite & - & - & 23.00 & - & 5.50 \\
\hline Cristobalite & - & - & 8.00 & 2.50 & - \\
\hline Diopside & - & - & 15.50 & - & - \\
\hline Calcite & - & - & 1.50 & - & - \\
\hline Tridymite & - & - & - & - & 36.00 \\
\hline Gahnite & - & - & - & - & 49.00 \\
\hline Hematite & - & - & - & 15.00 & - \\
\hline Gypsum & - & - & - & 10.00 & - \\
\hline Magnetite & - & - & - & 5.50 & - \\
\hline Coke & - & - & 10.00 & - & - \\
\hline Glass & - & - & - & 3.00 & 5.00 \\
\hline Cerussite & - & - & - & 2.00 & - \\
\hline Total & 100.00 & 100.00 & 100.00 & 100.00 & 100.00 \\
\hline
\end{tabular}

Katowice-Szopienice have similar compositions to those from other Polish sites. They are composed of pyroxene with the augite unit cell $\left((\mathrm{Ca}, \mathrm{Na})\left(\mathrm{Mg}, \mathrm{Fe}^{2+}, \mathrm{Al}, \mathrm{Fe}^{3+}, \mathrm{Ti}\right)\right.$ $\left.\left[(\mathrm{Si}, \mathrm{Al})_{2} \mathrm{O}_{6}\right] ; 62 \%\right)$, hematite $\left(\mathrm{Fe}_{2} \mathrm{O}_{3} ; 15 \%\right)$, gypsum $\left(\mathrm{CaSO}_{4} \times 2 \mathrm{H}_{2} \mathrm{O} ; 10 \%\right)$, magnetite $\left(\mathrm{Fe}_{3} \mathrm{O}_{4} ; 5.5 \%\right)$, cristobalite $(2.5 \%)$ and cerussite $\left(\mathrm{PbCO}_{3} ; 2 \%\right)$ (Fig. 2e; Table 1). The presence of small amounts of glass was determined (around 3\%). All the zincite was reduced during sintering, so no $\mathrm{Zn}$-rich phases were determined. The dominance of hematite over magnetite $(2.5: 1)$ suggests oxidizing conditions during the process. The local presence of gypsum and cerrusite is a result of sample storage without protection from weathering. According to EPMA data, pyroxene from the regular slag is augite with the complex formula: $\left(\mathrm{Ca}_{0.97} \mathrm{Na}_{0.02}\right)\left(\mathrm{Mg}_{0.61} \mathrm{Mn}_{0.02} \mathrm{Zn}_{0.01} \mathrm{Ti}_{0.02} \mathrm{Fe}_{0.09}^{2+} \mathrm{Fe}_{0.20}^{3+} \mathrm{Al}_{0.07}\right)$ $\left(\mathrm{Si}_{1.70} \mathrm{Al}_{0.30}\right) \mathrm{O}_{6}$, with characteristic $\mathrm{Zn}$ and $\mathrm{Mn}$ enrichment (Table 2). Hematite is almost pure $\mathrm{Fe}_{2} \mathrm{O}_{3}$ (up to 99.74 wt.\%), with sporadical enrichment in Mn (up to $1.11 \mathrm{wt} . \%$ $\mathrm{MnO}$ ), $\mathrm{Zn}$ (up to 0.35 wt. $\% \mathrm{ZnO}$ ) and $\mathrm{Pb}$ (up to 0.10 wt.\% $\mathrm{PbO}$ ) (Table 2). Spinel in slags is represented by magnetite enriched in gahnite $\left(\mathrm{ZnAl}_{2} \mathrm{O}_{4}\right)$-franklinite $\left(\mathrm{ZnFe}_{2} \mathrm{O}_{4}\right)$ and magnesioferrite $\left(\mathrm{MgFe}_{2} \mathrm{O}_{4}\right)$-spinel sensu strico $\left(\mathrm{MgAl}_{2} \mathrm{O}_{4}\right)$ endmembers (Table 2).
Slag with lining material is a block $23 \mathrm{~cm}$ across, with a clearly visible boundary between the slag and lining parts (Fig. 2f). The lining is yellow to brown in colour, and contains quartz grains up to $3 \mathrm{~mm}$ in size, dispersed in a matrix. Silica- and alumina-rich phases (e.g. quartz, mullite) are typical components of the lining material. The slag part of the sample is pale- to dark-gray with dispersed quartz grains up to $3 \mathrm{~mm}$ in size. The slag is composed of spinel (49\%), accompanied by tridymite $\left(\mathrm{SiO}_{2}, 36 \%\right)$, quartz $(4.5 \%)$, mullite $(5.5 \%)$ and glass $(5 \%)$ (Fig. $2 \mathrm{~g}-\mathrm{h}$, Table 1). Spinel crystallization around vesicles or lining "xenoliths" is a feature commonly found in pyrometallurgical slags, resulting from undercooling and local oxidizing conditions (Warchulski et al. 2015). Spinel in slag at the contact with the lining portions is represented by almost pure gahnite (mean composition: $\left(\mathrm{Zn}_{0.77} \mathrm{Fe}_{0.13} \mathrm{Mg}_{0.08} \mathrm{Na}_{0.05}\right)\left(\mathrm{Al}_{1.99} \mathrm{Ti}_{0.01}\right) \mathrm{O}_{4}$, Table 2) enriched in magnesioferrite-spinel sensu strico endmemebers. The silicate glass has a complex chemical composition with high $\mathrm{Fe}_{2} \mathrm{O}_{3}$ and $\mathrm{ZnO}$ contents (Table 2). The large amount of iron in the glass and the presence of Fe-depleted spinel are typical of undercooling conditions, where $\mathrm{Zn}$ and $\mathrm{Al}$ are preferentially bounded into spinel structure. This observation is in agreement with common spinel zoning in 
Table 2 Representative EPMA data (wt. \%) for pyroxene, hematite, spinel and glass

\begin{tabular}{|c|c|c|c|c|c|c|c|c|c|c|c|}
\hline \multicolumn{6}{|l|}{ Slag } & \multicolumn{6}{|c|}{ Slag with lining material } \\
\hline & $\operatorname{cpx} 1$ & $\operatorname{cpx} 2$ & hem 1 & hem 2 & spl 1 & spl 2 & spl 1 & spl 2 & spl 3 & gls 1 & gls 2 \\
\hline $\mathrm{SO}_{3}$ & 0.00 & 0.00 & 0.00 & 0.00 & 0.00 & 0.00 & 0.00 & 0.00 & 0.00 & 0.23 & 0.02 \\
\hline $\mathrm{SiO}_{2}$ & 46.76 & 42.90 & 0.00 & 0.00 & 0.00 & 0.15 & 0.00 & 0.00 & 0.00 & 53.72 & 63.50 \\
\hline $\mathrm{TiO}_{2}$ & 0.82 & 0.76 & 0.00 & 0.00 & 3.77 & 3.15 & 0.38 & 0.36 & 0.39 & 0.91 & 0.38 \\
\hline $\mathrm{Al}_{2} \mathrm{O}_{3}$ & 7.19 & 9.27 & 0.00 & 0.00 & 8.91 & 11.46 & 56.19 & 56.95 & 56.11 & 11.29 & 8.91 \\
\hline $\mathrm{Fe}_{2} \mathrm{O}_{3}$ & 4.47 & 9.28 & 99.74 & 98.74 & 55.73 & 54.15 & 0.00 & 0.00 & 0.00 & 21.28 & 16.25 \\
\hline $\mathrm{FeO}$ & 3.60 & 1.80 & 0.00 & 0.00 & 26.08 & 23.53 & 9.30 & 3.46 & 3.16 & 0.00 & 0.00 \\
\hline $\mathrm{MnO}$ & 0.70 & 0.31 & 0.40 & 1.11 & 1.73 & 2.23 & 0.30 & 0.00 & 0.00 & 1.41 & 1.30 \\
\hline $\mathrm{ZnO}$ & 0.37 & 0.42 & 0.00 & 0.35 & 1.77 & 1.70 & 31.64 & 35.31 & 37.33 & 6.07 & 3.54 \\
\hline $\mathrm{PbO}$ & 0.11 & 0.00 & 0.00 & 0.10 & 0.00 & 0.00 & 0.00 & 0.00 & 0.00 & 0.45 & 0.98 \\
\hline $\mathrm{MgO}$ & 11.17 & 10.45 & 0.00 & 0.00 & 2.01 & 3.47 & 1.80 & 2.25 & 1.09 & 0.91 & 0.55 \\
\hline $\mathrm{CaO}$ & 23.96 & 23.97 & 0.00 & 0.00 & 0.16 & 0.00 & 0.00 & 0.00 & 0.00 & 1.76 & 1.71 \\
\hline $\mathrm{K}_{2} \mathrm{O}$ & 0.00 & 0.00 & 0.00 & 0.00 & 0.00 & 0.00 & 0.00 & 0.00 & 0.00 & 2.18 & 2.65 \\
\hline $\mathrm{Na}_{2} \mathrm{O}$ & 0.27 & 0.21 & 0.00 & 0.00 & 0.00 & 0.00 & 0.81 & 0.99 & 1.02 & 0.28 & 0.22 \\
\hline Total & 99.42 & 99.36 & 100.15 & 100.30 & 100.15 & 99.83 & 100.42 & 99.32 & 99.10 & 100.49 & 100.01 \\
\hline \multicolumn{12}{|c|}{ Atoms per formula units } \\
\hline S & 0.00 & 0.00 & 0.00 & 0.00 & 0.00 & 0.00 & 0.00 & 0.00 & 0.00 & - & - \\
\hline $\mathrm{Si}$ & 1.76 & 1.64 & 0.00 & 0.00 & 0.00 & 0.01 & 0.00 & 0.00 & 0.00 & - & - \\
\hline $\mathrm{Ti}^{4+}$ & 0.02 & 0.02 & 0.00 & 0.00 & 0.10 & 0.08 & 0.01 & 0.01 & 0.01 & - & - \\
\hline $\mathrm{Al}$ & 0.32 & 0.42 & 0.00 & 0.00 & 0.37 & 0.47 & 1.97 & 2.00 & 2.00 & - & - \\
\hline $\mathrm{Fe}^{3+}$ & 0.13 & 0.27 & 1.99 & 1.98 & 1.50 & 1.42 & 0.00 & 0.00 & 0.00 & - & - \\
\hline $\mathrm{Fe}^{2+}$ & 0.11 & 0.06 & 0.00 & 0.00 & 0.78 & 0.69 & 0.23 & 0.09 & 0.08 & - & - \\
\hline $\mathrm{Mn}$ & 0.02 & 0.01 & 0.01 & 0.02 & 0.05 & 0.07 & 0.01 & 0.00 & 0.00 & - & - \\
\hline $\mathrm{Zn}$ & 0.01 & 0.01 & 0.00 & 0.01 & 0.05 & 0.04 & 0.69 & 0.78 & 0.83 & - & - \\
\hline $\mathrm{Pb}$ & 0.00 & 0.00 & 0.00 & 0.00 & 0.00 & 0.00 & 0.00 & 0.00 & 0.00 & - & - \\
\hline $\mathrm{Mg}$ & 0.63 & 0.59 & 0.00 & 0.00 & 0.11 & 0.18 & 0.08 & 0.10 & 0.05 & - & - \\
\hline $\mathrm{Ca}$ & 0.97 & 0.98 & 0.00 & 0.00 & 0.01 & 0.00 & 0.00 & 0.00 & 0.00 & - & - \\
\hline $\mathrm{K}$ & 0.00 & 0.00 & 0.00 & 0.00 & 0.00 & 0.00 & 0.00 & 0.00 & 0.00 & - & - \\
\hline $\mathrm{N}$ & 0.02 & 0.02 & 0.00 & 0.00 & 0.00 & 0.00 & 0.05 & 0.06 & 0.06 & - & - \\
\hline $\mathrm{O}$ & 6.00 & 6.00 & 3.00 & 3.00 & 4.00 & 4.00 & 4.00 & 4.00 & 4.00 & - & - \\
\hline
\end{tabular}

cpx clinopyroxene, hem hematite, $s p l$ spinel, gls glass

pyrometallurgical $\mathrm{Zn}-\mathrm{Pb}$ slags, where the core is rich in $\mathrm{Mg}$, $\mathrm{Zn}$ and $\mathrm{Al}$, whilst the rim has a composition close to magnetite (Kucha et al. 1996; Ettler et al. 2001; Warchulski et al. 2015, 2016).

\section{Chemical composition and modelling of the smelting process}

\section{Enriched ore}

Enriched ore is composed mainly of $\mathrm{Zn} \mathrm{(56.67} \mathrm{wt. \% ),}$ $\mathrm{S}$ (26.60 wt.\%), Fe (3.44 wt.\%), Pb (1.45 wt.\%) and $\mathrm{Ca}$ (0.87 wt.\%) (Table 3). This chemical composition is typical of enriched ore composed of $\mathrm{Zn}, \mathrm{Fe}, \mathrm{Pb}$ sulphides in dolomitic rocks, as described on the basis of historical data and XRD analysis.

\section{Roasted ore}

Ore after roasting consists of $\mathrm{Zn}$ (58.72 wt.\%), $\mathrm{Pb}$ (3.91 wt.\%), S (3.79 wt.\%), Ca (3.27 wt.\%), Fe (1.92 wt.\%), $\mathrm{Mg}$ (1.56 wt.\%) and Si (1.54 wt.\%) (Table 3). The sample composition perfectly mirrors historical descriptions. It also corresponds to the XRD data, where most of the $\mathrm{Zn}$ is present as zincite, and the high $\mathrm{Mg}$ and $\mathrm{Ca}$ contents are explained by the presence of dolomite; $\mathrm{Pb}$ after oxidization was able to crystallize as platterite. Residual sulphur is related to minor amounts of sphalerite. Normalization of the 

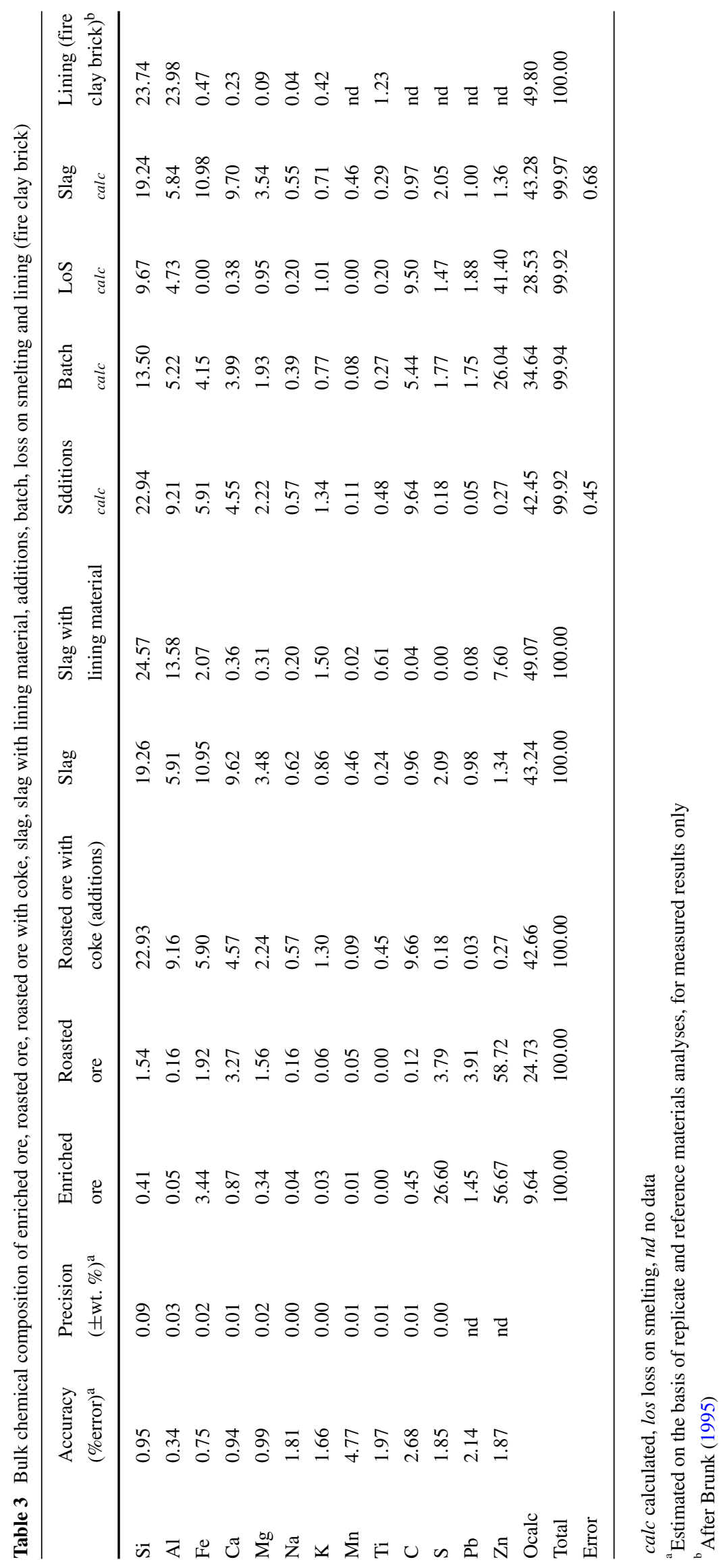
chemical composition of roasted ore to enriched ore shows (Fig. 3) significant enrichment of the first in $\mathrm{Si}, \mathrm{Al}, \mathrm{Ca}, \mathrm{Mg}$, $\mathrm{Na}, \mathrm{K}$ and $\mathrm{Pb}$, with simultaneous impoverishment in $\mathrm{Fe}, \mathrm{C}$ and $\mathrm{S}$.

Roasted ore with coke. Although due to historical descriptions the chemical composition of this sample should correspond to roasted ore but enriched in $\mathrm{C}$, it differs significantly (Fig. 3). Roasted ore with coke is composed of Si (22.93 wt.\%), C (9.66 wt.\%), Al (9.16 wt.\%), Fe (5.90 wt.\%), Ca (4.57 wt.\%), Mg (2.24 wt.\%) and K (1.30 wt.\%) (Table 3). Such a composition confirms the XRD analysis of the sample, and raises the same question about the accuracy of historical descriptions of the sample. It is highly unlikely that a sample with such $\mathrm{Zn}$ concentrations $(0.27$ wt.\%; Table 3) was used for smelting.

\section{Slag}

The slag sample is composed mainly of Si (19.26 wt.\%), $\mathrm{Fe}$ (10.95 wt.\%), Ca (9.62 wt.\%), Al (5.91 wt.\%), Mg (3.48 wt.\%), S (2.09 wt.\%) and Zn (1.34 wt.\%) (Table 3). In general, the slag composition is similar to that of other pyrometallurgical $\mathrm{Zn}-\mathrm{Pb}$ slags from Upper Silesia (Puziewicz et al. 2007; Warchulski et al. 2015, 2016). Normalization of the investigated slag to roasted ore (Fig. 3) shows enrichment in the elements typically connected to the fluxing material and quartz sand additions $(\mathrm{Si}, \mathrm{Al}, \mathrm{Fe}, \mathrm{Ca}, \mathrm{Mg}, \mathrm{Na}$, $\mathrm{K}$ and $\mathrm{C}$ ) and impoverishment of $\mathrm{S}, \mathrm{Pb}$ and $\mathrm{Zn}$.

\section{Slag with lining material}

Slag at the contact with the lining material shows a different composition to the regular slag. The sample is composed of $\mathrm{Si}$ (24.57 wt.\%), $\mathrm{Al}$ (13.58 wt.\%), Zn (7.60 wt.\%), Fe (2.07 wt.\%) and K (1.50 wt.\%) (Table 3). The chemical composition corresponds to the XRD data. When compared to the regular slag (Fig. 3), the analyzed sample is enriched in $\mathrm{Al}$, $\mathrm{K}, \mathrm{Ti}, \mathrm{P}$ and $\mathrm{Zn}$. The simple phase composition may be explained by impoverishment in many mineral-forming elements: $\mathrm{Fe}, \mathrm{Ca}, \mathrm{Mg}, \mathrm{Na}, \mathrm{C}, \mathrm{S}$ and $\mathrm{Pb}$ (Fig. 3). On the other hand, slag with lining material has a composition similar to roasted ore with coke with high $\mathrm{Si}, \mathrm{Al}$ and $\mathrm{K}$ contents, which supports the theory that the lining might have been recycled and together with coke used as additions, and was mistakenly described as roasted ore with coke.

\section{Historical process in the light of geochemistry, petrology and evolutionary computations}

\section{Restoration of the smelting process at the Katowice-Szopienice site}

The primary goal of this paper was to describe the smelting process at the Katowice-Szopienice site. The analyses proved that the $\mathrm{Zn}-\mathrm{Pb}$ ore underwent significant transformations of phase composition and chemistry during smelting. According to historical descriptions, the first step of the process involved enrichment of the ore. We observe a significant leap of zinc content as the result of its processing: original ores from Upper Silesia contained $13 \mathrm{wt} . \%$ of $\mathrm{Zn}$ on average (Dobis 1938), whilst the enriched ore concentrates 57 wt.\% of this element (Table 3).

The next step involved roasting of the ore. Geochemical and petrographical data confirm that thesis. Enriched ore concentrating high amounts of sulphur, lead (in a form of galena), zinc (mainly as sphalerite and wurtzite) and iron (marcasite and pyrite) after roasting became sulphur depleted. As sulphur was oxidized and removed from the system, the phase composition changed: $\mathrm{ZnS}$ phases were replaced by zincite and, with combination with iron, franklinite. Lead present in sulphides as a minor element during roasting was also oxidized to form plattnerite. Both chemical and phase changes point to high temperatures during the process in the presence of free oxygen, which fits perfectly with the assumed roasting conditions. It is doubtful that the
Fig. 3 Normalization of chemical composition of : $(I)$ roasted ore to enriched ore, $(I I)$ slag to roasted ore, (III) slag with lining material to slag and (IV) slag with lining material to roasted ore with coke

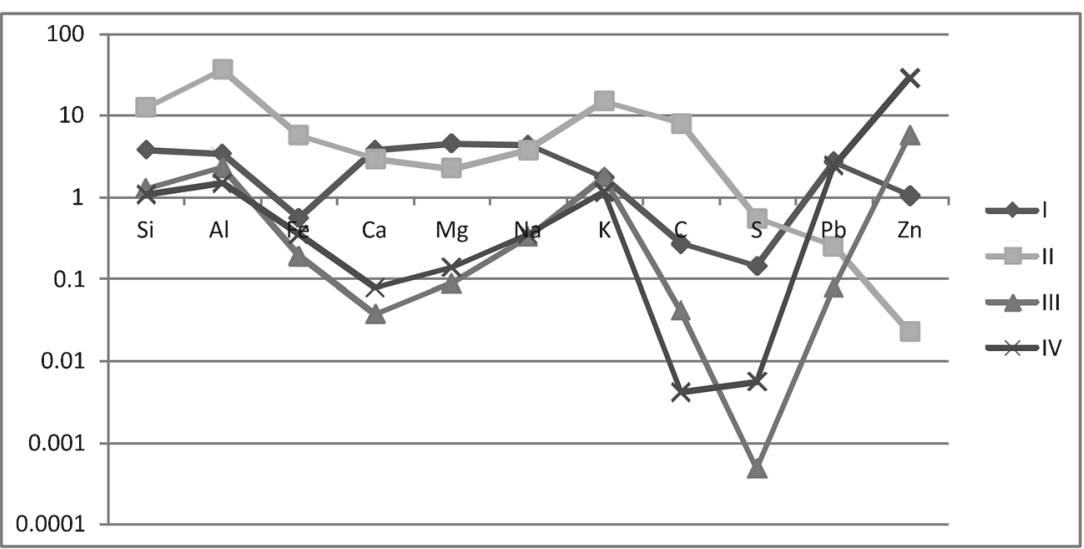


roasted ore with coke sample actually contains the described material. Our results suggest that the sample probably contains recycled lining material with coke additions and during further discussion it will be treated in such a way.

When comparing the examined slag to the roasted ore, we observe changes typical of the smelting process (Fig. 3): decreases in the $\mathrm{Zn}, \mathrm{Pb}$ and $\mathrm{S}$ contents, which were removed from the system, and enrichment in $\mathrm{Si}, \mathrm{Al}, \mathrm{Ca}, \mathrm{Mg}, \mathrm{K}$ (the source of these elements are additions to the ore). These qualitative observations were completed by data received from the evolutionary computations. The only assumptions were: the composition of roasted ore and proportion of roasted ore to additions in range of 1:1.2-1:1.5 (proportion $1: 1.2$ provides the lowest possible amount of $\mathrm{C}$ for a full reduction of $\mathrm{ZnO}$ and the proportion 1:1.5 was proposed as an economic factor in the smelting). The differential evolution algorithm was used for 100 analyses, providing such amounts of calculated compositions of additions, loss on smelting and slag (Fig. 4a). The algorithm matched also 100 different proportions of roasted ore to additions, and the same of the loss on smelting fraction from the batch (Fig. 4b). We obtained low dispersed results that are comparable with differences on the level of a few tenths of a percent on each element for additions and slag and few percents for loss on smelting (Fig. 4a). Such diversity in case of loss on smelting is caused directly by algorithm fitting calculated results for additions and slag to actually measured whilst the loss on ignition values are in a way a result of this fitting. The received data for the proportion of roasted ore to additions show a wide spread in the boundaries of the proposed range $(1: 1.2-1: 1.5)$, whilst the fraction of the loss on smelting is more constant (ca. 0.5-0.7), thus the proportion of the roasted ore to additions seems to have had a great influence on the final result. As a measure of the best fit of results, $\Sigma$ error was proposed where $\Sigma$ error is the total error received from the absolute value of differences on each element of additions-additions calc $_{\text {and }}$ alag-slag calc $_{\text {. }}$. All received $\Sigma$ errors are within the range of about 1 and 4.5 wt $\%$, with the best fit of 1.19 wt $\%$ (Fig. 4c; $n=71$ ). This result would be treated as model in further discussion. a

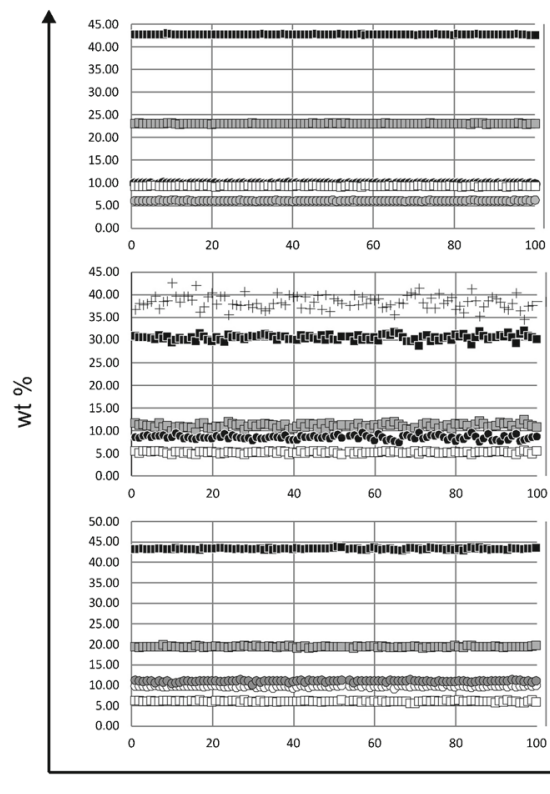

elements 1 - 5 wt \%
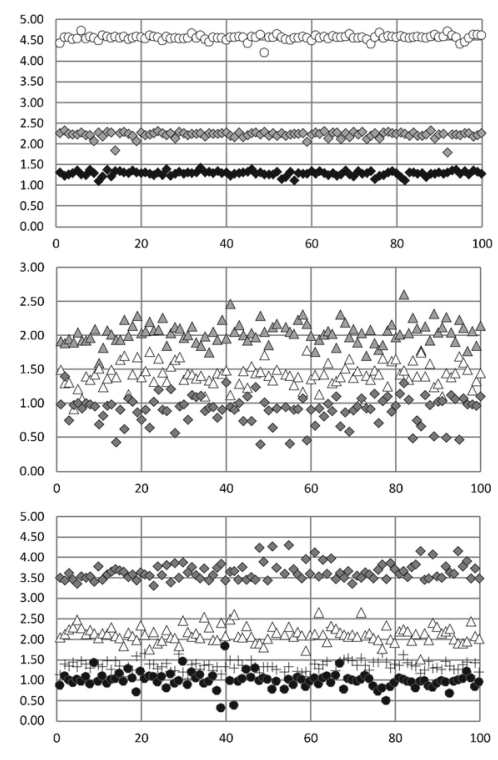

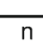

- $\mathrm{O} \quad \square \mathrm{Si} \quad \square \mathrm{Al} \quad \bullet \quad \mathrm{C} \quad \mathrm{OF} \quad \mathrm{OCa} \quad \mathrm{K} \quad \Delta \mathrm{Mg} \quad \diamond \mathrm{Mn} \quad \Delta \mathrm{Na} \quad \Delta \mathrm{Pb} \quad \Delta \mathrm{S} \quad \times \mathrm{Ti} \quad+\mathrm{Zn}$
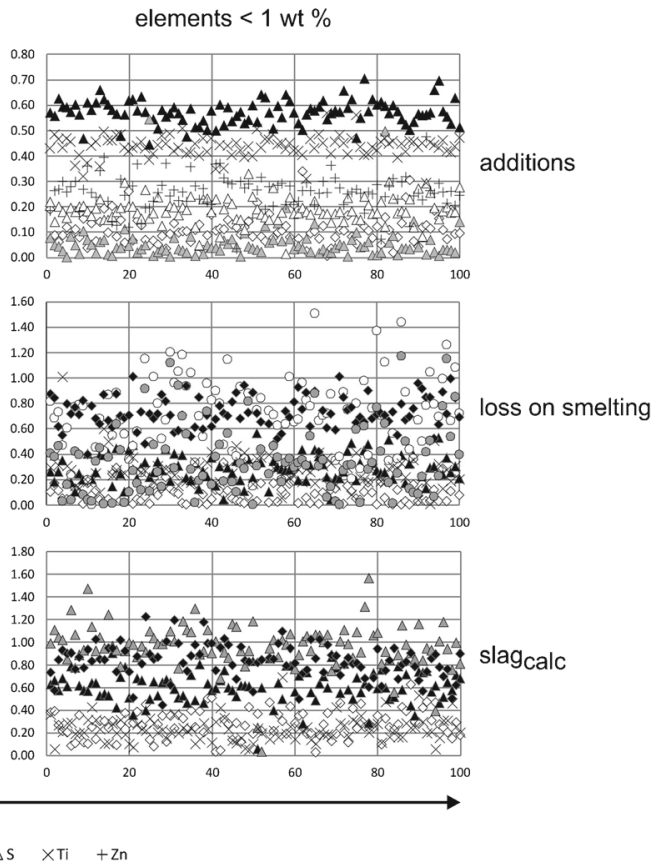

b

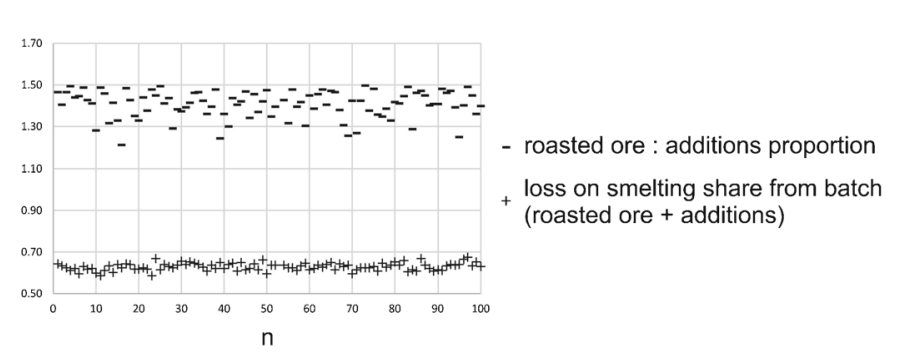

C

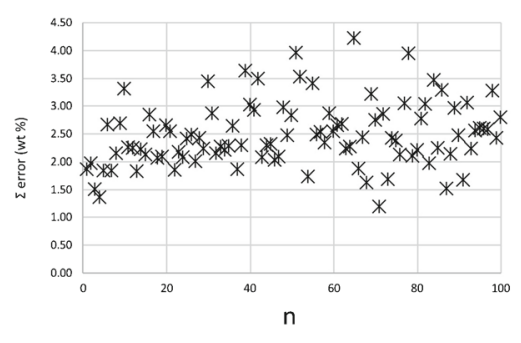

Fig. 4 a Calculated chemical compositions of additions, loss on smelting and slag; $\mathbf{b}$ calculated proportion of roasted ore to additions and loss on smelting share from batch; $\mathbf{c}$ calculated total error. calc calculated, $n$ analyse number 
Before smelting, a batch was formed by mixing of the roasted ore and the additions in proportion of 1:1.27. The batch was loaded to heated muffles where it was melted at temperatures in the range ca. $1060-1350{ }^{\circ} \mathrm{C}$ (Warchulski 2015). During smelting, the batch underwent many physical and chemical transformations, among which the most important is reduction of $\mathrm{ZnO}$ by $\mathrm{C}$ as follows:

$2 \mathrm{ZnO}+C \rightarrow 2 \mathrm{Zn}($ gas $)+\mathrm{CO}_{2}$

The products of this reaction are removed from the muffle, thus with other easily reduced compounds (with $\mathrm{S}$ and $\mathrm{Pb}$ ) they supply the loss on smelting. When comparing the calculated loss on smelting (Table 3 ) with the above equation, we see that the results of the algorithm perfectly mirror the equation. The calculated loss on smelting, as was expected, is rich in $\mathrm{Zn}, \mathrm{O}, \mathrm{C}, \mathrm{Pb}$ and $\mathrm{S}$. On the other hand, the high contents of $\mathrm{Si}$ and $\mathrm{Al}$ are surprising (Table 3). A possible explanation is the differences in composition of the roasted ore, additions and slag causing extra amounts of $\mathrm{Si}$ and $\mathrm{Al}$ in the last step of the algorithm. It is, however, doubtful that all compounds were made in the same particular smelting process. Another explanation involves the influence of undercooling conditions at the contact with the lining. According to the received data, about $62 \%$ of the batch was removed as loss on smelting, whilst the other $38 \%$ formed the slag. The slag composition is influenced by the described changes during smelting. In comparison with the batch (Table 3), it is depleted in $\mathrm{Zn}, \mathrm{O}, \mathrm{C}, \mathrm{Pb}, \mathrm{S}$ and thus proportionally enriched in other elements especially $\mathrm{Si}, \mathrm{Al}, \mathrm{Ca}, \mathrm{Fe}$ and $\mathrm{Mg}$. The algorithm fitting on slag is almost perfect with

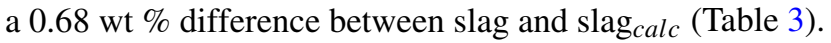

Slag with lining material is enriched in $\mathrm{Si}, \mathrm{Al}, \mathrm{K}$ and $\mathrm{Zn}$ and depleted in $\mathrm{Fe}, \mathrm{Ca}, \mathrm{Mg}, \mathrm{S}$ and $\mathrm{Pb}$ when compared to the regular slag (Fig. 3). The influence of the lining material should be separated into chemical and physical effects. Chemical effects resulted in the presence of phases typical of the lining: mullite, tridymite and migration of Al from mullite to melt, causing crystallization of Al-rich spinel, showing a gahnite composition and unit cell parameters (Table 3). The physical effect resulted in undercooling, causing the formation of a simple melt-related phase-assemblage - spinel + quartz + glass. Crystallization of $\mathrm{Al}$ rich spinel $\left(\mathrm{ZnAl}_{2} \mathrm{O}_{4}\right)$ and quartz may also have been a result of the enrichment of melt in $\mathrm{Si}$ and $\mathrm{Al}$ from loss on smelting. In this case, some amount of Si and Al would be trapped on the boundary with lining and thus would not migrate to the slag, explaining the elevated amounts of this elements in the loss on smelting.

\section{Petrographical and geochemical verification of historical descriptions}

A secondary goal of our study was to verify the historical description of samples received at the Museum of Zinc in
Katowice: enriched ore, roasted ore and roasted ore with coke. XRD data and chemical analyses proved that the enriched ore description fits to the sample phase composition (zinc and iron sulphides accompanied by low content of anglesite and dolomite), composition ( $\mathrm{Zn}, \mathrm{S}, \mathrm{Fe}$ and $\mathrm{Pb}$ as main elements) and optical properties (yellow-greenish grains up to few millimetres).

The qualitative analyses of the roasted ore sample mirror possible changes of enriched ore as the result of roasting: impoverishment in sulphur with the presence of oxidized phases, mainly zincite. On the other hand, quantitative XRD and chemical analyses do not match the supposed changes (e.g. the higher content of dolomite in the roasted ore). The most plausible explanation is that those samples were collected not from the same particular roasting process. That suggests also the high diversity of possible sample composition resulting from the same process or the differences in primary ore composition. According to the historical descriptions (Dobis 1938), it is also possible that the enriched ore and roasted ore samples have a different place of origin.

Investigations presented in this study suggest a wrong historical description of the roasted ore with coke sample. Macroscopic properties, X-ray diffraction data and bulk sample chemistry suggest that the sample may contain recycled fire clay brick used as lining material in the smelting. When comparing the roasted ore with coke sample phase composition with typical fire clay brick, we observe compositional similarities, with a predominance of mullite, cristobalite and quartz/glass in both, differing only in phase proportions (Table 1). The roasted ore with coke sample is impoverished in mullite (23 vs. 60-65\%) and cristobalite ( 8 vs. $20-25 \%$ ) and enriched in quartz (42 vs. 15-20\%), which consequently influences the chemical composition. Both the roasted ore with coke sample and fire clay brick (Brunk 1995; Routschka and Wuthnow 2008) are rich in $\mathrm{Al}_{2} \mathrm{O}_{3}$ and $\mathrm{SiO}_{2}$, but the roasted ore with coke is Al- $(9.26$ vs. 23.98 wt.\%) and Fe- (5.90 vs. 19.88) depleted, and enriched in $\mathrm{Ca}$ (4.57 vs. 0.23 wt.\%), $\mathrm{Mg}$ (2.24 vs. 0.09 wt.\%) and $\mathrm{K}$ (1.30 vs. 0.42 wt.\%). Assuming that this sample represents a recycled lining material after smelting, quantitative differences are easy to understand. When comparing the roasted ore with coke with the slag with lining material, it is visible that their chemistry is more comparable with the composition of fire brick clay (lining). The phase composition of the slag with lining material explains the impoverishment of the roasted ore with coke sample in aluminium and gain in silica. As the result of smelting, mullite from the lining was melted and enriched the melt in $\mathrm{Al}$, leading to the crystallization of gahnite, whilst $\mathrm{Si}$ gain led to the crystallization of additional quartz.

The slag and slag with lining material samples were not historically described, but collected during Katowice- 
Szopienice site inspection; thus, the goal here was not to confirm the historical data but to confirm if they are in fact slag samples locally containing the lining material. Electron-probe and XRD analyses proved that both samples underwent smelting - they are composed of high temperature phases common in pyrometallurgical $\mathrm{Zn}-\mathrm{Pb}$ slags (Warchulski et al. 2015, 2016), e.g. pyroxene, spinel, $\mathrm{SiO}_{2}$ polymorphs. Moreover, both samples differ significantly in phase composition and chemistry. The slag sample corresponds to regular slag material after $\mathrm{Zn}-\mathrm{Pb}$ ore smelting (Warchulski et al. 2015, 2016), whilst the slag with lining material contains high amounts of phases related to fire clay bricks, e.g. mullite and tridymite, with only one purely slag-related phase-gahnite.

\section{Summary-geochemical and petrographic investigations as a tool for archaeology}

Four general geochemical and petrographical tools were used in this study: microscopic observation of morphology and optical properties; X-ray diffraction for phase compositions; electron-probe microanalysis with BSE imaging for phase chemical composition and analysis of phase relationships; bulk chemical analyses (ICP-MS and XRF) for slag chemistry compositions mistakes, but also to revise them. Enriched ore and roasted ore samples were confirmed by all methods to fit to the description. Moreover, comparison of phase and chemical compositions proved that these samples were not collected from the same particular technological line. But the great usefulness of petrographical and geochemical methodologies was proven in the case of the sample described as roasted ore with coke. All the applied techniques pointed to an error in the description of this sample, except the coke content indicating a link with the smelting process. Extensive analysis allowed us to identify this sample as recycled lining material mixed with coke, used as an addition in the smelting. For the slag, the methodology allowed us to confirm that this material corresponds to other $\mathrm{Zn}-\mathrm{Pb}$ slags from Poland (Puziewicz et al. 2007; Warchulski et al. 2015, 2016). In the sample described as slag with lining material, the presence of lining components was confirmed. Whilst typical geochemical tools gave general "more-or less" qualitative data, the evolutionary computations provided us with high quality quantative results. With differential evolutionary algorithm, we were able not only to calculate possible loss during smelting, but also answer question about the proportion of roasted ore and additions used for the batch, and the approximate percentage of loss on smelting from the batch. All the results fit perfectly to the historical description, petrographical and geochemical observations, simultaneously resulting in a very low quantitative error ( $\Sigma$ error down to 1.19 wt \%).

Acknowledgments This study was was supported by NCN 53 grant No. 2014/13/B/ST10/02403, entitled "Zinc and lead metallurgical slags - testing ground for investigation of behaviour of potentially toxic elements in the crystal phase structures and their interaction with environment" given to AG and supported by the grant of Centre for Polar Studies, University of Silesia, Poland-The Leading National Research Centre (KNOW) in Earth Sciences 2014-2018 given to RW.

Open Access This article is distributed under the terms of the Creative Commons Attribution 4.0 International License (http:// creativecommons.org/licenses/by/4.0/), which permits unrestricted use, distribution, and reproduction in any medium, provided you give appropriate credit to the original author(s) and the source, provide a link to the Creative Commons license, and indicate if changes were made.

\section{Compliance with ethical standards}

Conflict of interests The authors declare that they have no conflict of interest.

\section{References}

Brunk F (1995) Corrosion and behaviour of fireclay brick used in the flues of open anode baking furnaces. Light Metals, 641-646

Dobis N (1938) Zinc and lead industries in Poland. Reprint of the calendar of mining and metallurgy, Katowice

Engelbrecht AP (2007) Computational Intelligence: An Introduction. Wiley 2nd edition

Ettler V, Legendre O, Bodénan Touray J-C (2001) Primary phases and natural weathering of old lead-zinc pyrometalurgical slag from Př́bram, Czech Republic. Can Mineral 39:873-888

Ettler V, Johan Z (2014) 12 years of leaching of contaminants from $\mathrm{Pb}$ smelter slags: Geochemical/mineralogical controls and slag recycling potential. Appl Geochem 40:97-103

Goldberg DE (1989) Genetic Algorithms in Search, Optimization, and Machine Learning. Addison-Wesley Professional

Greiner P (2004) My land Katowice (Moja Ziemia Katowice). Bractwo Gospodarcze Związku Górnośląskiego, Katowice, 42-48

Heijlen W, Muchez P, Banks DA, Schneider J, Kucha H, Keppens E (2003) Carbonate-Hosted Zn-Pb Deposits in upper silesia, Poland: Origin and evolution of mineralizing fluids and constraints on genetic models. Econ Geol 98:911-932

Kasemir KU (2003) Detecting ellipses of limited eccentricity in images with high noise levels. Image Vis Comput 21(7):221-227

Kierczak J, Bril H, Neel C, Puziewicz J (2010) Pyrometallurgical slags in Upper and Lower Silesia (Poland): from environmental risk to use of slag-based product - a review. Arch Environ Prot 36 (3):111-126

Kierczak J, Pietranik A (2011) Mineralogy and composition of historical $\mathrm{Cu}$ slags from the Rudawy Janowickie Mountains, southwestern Poland. Can Mineral 49:1281-1296

Kucha H, Martens A, Ottenburgs R, De Vos W, Viaene W (1996) Primary minerals of $\mathrm{Zn}-\mathrm{Pb}$ mining and metallurgical dumps and their environmental behavior at Plombières, Belgium. Environ Geol 27:1-15

Ladell J, Zagofsky A, Pearlman S (1975) Cu K $\alpha 2$ elimination algorithm. J Appl Crystallogr 8:499-506 
Manasse A, Mellini M (2002a) Archaeometallurgic slags from Kutna Horà. Neues Jahrbuch Für Mineralogie - Monatshefte 8:369-384

Manasse A, Mellini M (2002b) Chemical and textural characterisation of medieval slags from the Massa Marittima smelting sites (Tuscany, Italy). J Cult Herit 3:187-198

Piatak NM, Seal RRII (2010) Mineralogy and the release of trace elements from slag from the Hegeler Zinc smelter, Illinois (USA). Appl Geochem 25:302-320

Puziewicz J, Zainoun K, Bril H (2007) Primary phases in pyrometallurgical slags from a zinc-smelting waste dump, Świętochłowice, Upper Silesia, Poland. Can Mineral 45:1189-1200

Rachinger WA (1948) A correction for the $\alpha 1: \alpha 2$ doublet in the measurement of widths of $\mathrm{x}$-ray diffraction lines. J Sci Instrum 25:254-259

Routschka G, Wuthnow H (2008) Refractory materials: Pocket manual; design, properties testing. Vulkan Verlag, 3rd edition

Storn R (1996) Differential evolution design of an iir-Filter. IEEE International Conference on Evolutionary Computation ICEC96, 268-273
Storn R, Price K (1997) Differential evolution - a simple and efficient heuristic for global optimization over continuous spaces. J Glob Optim 11:341-359

Sybliski D, Kraszewski C, Duszyński A., Wileński P., Pachowski J, Mirski K (2004) Estimations and investigations of selected industrial wastes for the usage in road construction. Road and Bridge Research Institute, Warsaw

Warchulski R (2015) Zn-Pb slag crystallization: evaluating temperature conditions on the basis of geothermometry. European Journal of Mineralogy. doi:10.1127/ejm/2015/0027-2496

Warchulski R, Gawęda A., Kądziołka-Gaweł M., Szopa K (2015) Composition and element mobilization in pyrometallurgical slags from Orzeł, Biały smelting plant in the Bytom - Piekary Śląskie area, Poland. Min Mag 79(2):459-483

Warchulski R, Gawęda A, Janeczek J, Kądziołka-Gaweł M (2016) Mineralogy and origin of coarse-grained segregations in the pyrometallurgical $\mathrm{Zn}-\mathrm{Pb}$ slags from Katowice-Welnowiec (Poland). Mineralogy and Petrology. doi:10.1007/s00710-016-0439-1 